\title{
Radiographical and Macroscopical Visualization of Fourth Molars: a Report of Four Cases in Maxilla
}

\author{
Visualización Radiográfica y Macroscópica de Cuartos Molares: \\ un Reporte de Cuatro Casos en el Maxilar \\ Ramón Fuentes; Eduardo Borie \& Víctor Beltrán
}

FUENTES, R.; BORIE, E. \& BELTRÁN, V. Radiographical and macroscopical visualization of fourth molars: a report of four cases in maxilla. Int. J. Morphol., 30(1):115-118, 2012.

SUMMARY: Supernumerary teeth are defined as the existence of a higher number of teeth in relation to normal dental formula. The development of supernumerary teeth can happen at different times of the life and can be detected either, clinically or radiographically. The relation between supernumerary teeth and nonsyndromic cases have been reported once in a while in the literature. In this report are presented four cases of nonsyndromic patients with fourth molars in the maxilla, which were described macroscopically and radiographically.

KEY WORDS: Fourth molar; Supernumerary teeth; Radiograph.

\section{INTRODUCTION}

Tooth development results of several interactions between oral epithelium and underlying mesenchymatic tissue during odontogenesis (Fuentes \& Oporto, 2009; Borie et al., 2010). Dental anomalies can be the result of many factors, including genetic and environmental ones. Although defects in certain genes have the highest incidence, etiological events in prenatal and postnatal periods have also been blamed for anomalies in tooth dimension, morphology, position, number, and structure (Basdra et al., 2000; Uslu et al., 2009).

Supernumerary teeth are defined as the existence of a higher number of teeth in relation to normal dental formula (Leco Berrocal et al., 2007). The most of supernumerary teeth are considered to develop as a result of horizontal proliferation of the permanent or deciduous dental lamina (Refoua \& Arshad, 2006).

Regarding classification, supernumerary teeth that occur between or just posterior to the central incisors are referred to as "mesiodens"; those in the molar area are called "paramolar" teeth; and, more specifically, those that erupt distally to the third molar are "distomolar" teeth (Kokten $e t$ al., 2009). The majority of supernumerary cases are single teeth in a ratio of $77-86 \%$ (Rajab \& Hamdan, 2002; Orhan et al., 2006), and males are more affected with this condition than females (Rajab \& Hamdan; Duncan, 2009).

The development of supernumerary teeth can happen at different times of life and can be detected either, clinically or radiographically. Clinically, supernumerary teeth are capable of creating some different local disorders, such as retention of the primary tooth, delayed eruption of the permanent tooth, ectopic eruptions, tooth displacements, follicular cysts, and other alterations, requiring surgical or orthodontic intervention (De Oliveira Gomes et al., 2008; Celikoglu et al., 2010).

The relation between supernumerary teeth and nonsyndromic cases have been reported occasionally in the literature (Desai \& Shah, 2007; Duncan; Celikoglu et al.). Therefore, the aim of this article is to present four nonsyndromic cases with presence of a fourth molar in each patient, respectively.

\section{CASE REPORTS}

Case 1. A 24-year-old Chilean female patient came to dental control for routine examination. The extra-oral examination showed no abnormalities, and the intraoral investigation did not reveal the presence of caries and

Departmento de Odontología Integral, Universidad de La Frontera, Temuco, Chile. 
periodontal disease. Among the complementary tests that were requested, a panoramic radiograph was taken. In panoramic radiograph a fourth molar was identified in maxillary left side. Subsequently, a periapical radiograph of fourth molar was taken. Fourth molar had a distopalatine position (intraosseous) in relation with third molar (Fig. 1A). During anamnesis, the patient reported no history for systemic or syndromic diseases, she also related that no one in her family presented a fourth molar. After the tooth extraction procedure, it was cleaned and observed macroscopically. The size was a half of third molar (Fig. 2A). Its occlusal shape was similar with second mandibular premolars (Fig. 2B), with a crown-root relation of 1:1 and one fused root. Also, it had an $8 \mathrm{~mm}$ of total length, with coronary height of $4.14 \mathrm{~mm}$, mesial distal diameter of $5.5 \mathrm{~mm}$ and buccal-palatine diameter of 4.4 $\mathrm{mm}$.

Case 2. A 20-year-old Chilean male patient came for third molars extraction. Among the complementary tests that were requested, a panoramic radiograph was taken. In panoramic radiograph a fourth molar was identified in maxillary right side. Subsequently, a periapical radiograph of fourth molar was taken. In periapical radiograph the position of fourth molar was upper than crown of third molar, at root level, intraosseous (Fig. 1B). The patient reported no history of syndromic or systemic diseases and no one in his family has presented a supernumerary tooth.

Case 3. A 37-year-old Chilean female patient came for pain related to upper left third molar. In the periapical radiograph a fourth molar was identified in maxillary left side. Fourth molar position was upper than crown of third molar, at root level, intraosseous (Fig. 1C). The patient reported no history of syndromic or systemic diseases and no one in her family has presented a supernumerary tooth.

Case 4. A 34-year-old Chilean male patient was assessed to be treated for periodontal therapy. In the routine radiographs requested for periodontal therapy a fourth molar was identified in maxillary left side. A cone beam of fourth molar zone was taken. In relation with fourth molar position, it was observed between second and third molar but with a buccal position and upper than both (Fig. 1D). During anamnesis, the patient reported no history of systemic or syndromic diseases. After the tooth extraction procedure, it was cleaned and observed macroscopically. It occlusal shape was very irregular (Fig. 2D), with a crown-root relation of 1:2 and one fused root (Fig. 2C). Also, it had an $9.19 \mathrm{~mm}$ of total length, with coronary height of $3.08 \mathrm{~mm}$, mesial distal diameter of $4.15 \mathrm{~mm}$ and buccal-palatine diameter of $7.25 \mathrm{~mm}$.
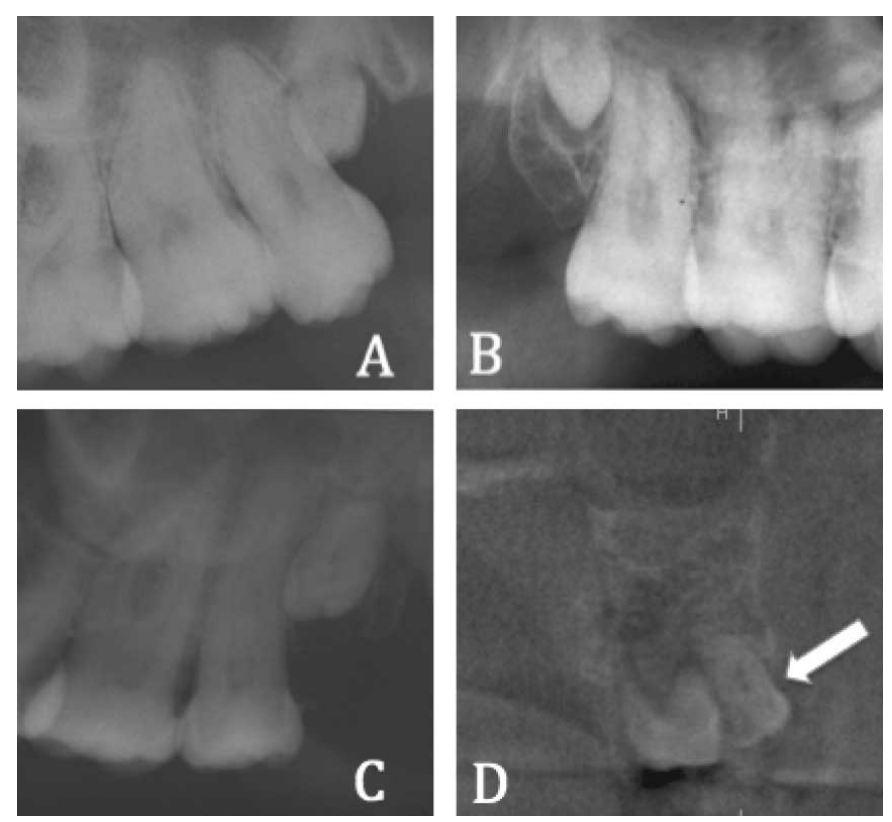

Fig. 1. Radiographs of all fourth molar cases. A. Fourth molar in left side (case 1). B. Fourth molar in right side (case 2). C. Fourth molar in left side (case 3). D. Cone beam of fourth molar zone (white arrow, case 4).
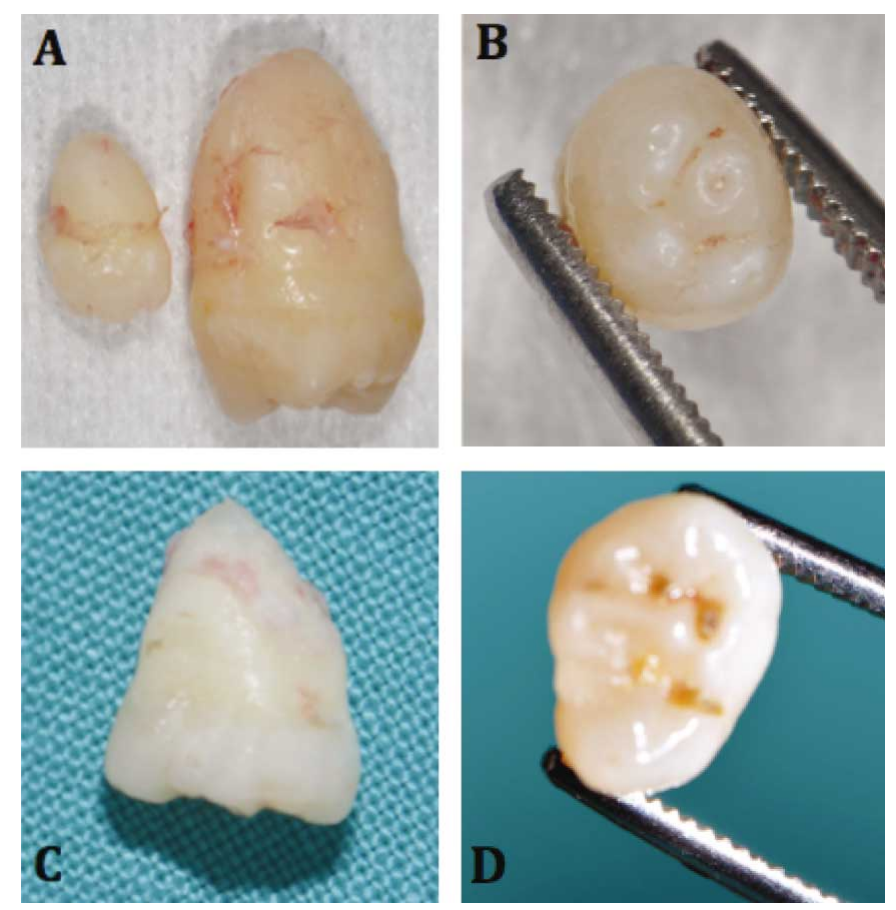

Fig. 2. Macroscopic view of fourth molar. A. Note that fourth molar size was a half of third molar extracted with one fused root too (case 1). B. Occlusal view of fourth molar (case 1). Note that occlusal shape is similar with mandibular second premolar with predominance of mesio-distal diameter. C. Lateral view of fourth molar with and irregular shape and predominance of root length (case 4). D. Occlusal view of fourth molar (case 4). Note that occlusal shape is irregular with predominance of buccal-palatine diameter. 


\section{DISCUSSION}

Gay et al. (1999) have reported a low prevalence between $0.13 \%$ and $0.6 \%$ for fourth molars. Salcido-García et al. (2004) revealed that fourth molars generally are radiographic findings and that $93.2 \%$ of patients come spontaneously and without associated pathology. Among the complementary tests that are needed to identify a fourth molar, the panoramic radiograph is the first choice for diagnosis. However, this test does not give details and high definition and could be distorted (Hopcraft, 1998; Cortés et al., 2009).

Orhan et al. mentioned that supernumerary teeth can be observed as isolated or multiple cases, unilateral or bilateral and in mandible or maxilla. In this report, all fourth molars were identified isolated and unilateral in maxilla. It could be supported by some authors (Stafne, 1935; Pindborg, 1970; Grimanis et al., 1991; Sheiner \& Sampson, 1997; Menardia-Pejuan et al., 2000; Rajab \& Hamdan). Three of fourth molars were "distomolars" and one case was "paramolar" according to Kokten et al. classification. Supernumerary teeth reported were more often found in males than females (Pindborg; Timocin et al., 1994) but in these four cases fourth molars were found in the same malefemale ratio.

Cortés et al. mentioned that the $95 \%$ of cases of supernumerary teeth are impacted; however, none of fourth molars reported in this case were impacted. One of four ca- ses had an ectopic eruption concurring with De Oliveira Gomes et al. and Celikoglu et al.

In the case 1 the crown-root relation was 1:1 similar to all cases reported by Kokten et al.; however, in this report case 4 presented a crown-root relation of 1:2. Regarding fourth molar measurements, in cases 1 and 4 the total height observed ( $8 \mathrm{~mm}$ and $9.19 \mathrm{~mm}$ ) was lesser than Kokten et al. cases (13 mm, $10 \mathrm{~mm}$ and $13.64 \mathrm{~mm})$. Similar results were identified in crown height and crown width. Also, all cases of fourth molars reported in the literature had fused roots. It is important to note that in case 1 the buccal-palatine diameter predominates over mesio-distal diameter. On the other hand, in case 4 mesio-distal diameter predominates over buccal-palatine diameter.

Qaradaghi et al. (2009) states that supernumerary teeth can have normal morphology or may be rudimentary in shape and smaller in size. In case 1 the fourth molar presented normal morphology with two tubercles, similar with the three cases reported by Kokten et al. On the other hand, case four concurs with Qaradaghi et al., because in this fourth molar an irregular shape and size could be observed.

Finally in this report, all cases were identified in nonsyndromic patients concurring with Desai \& Shah and Duncan.

FUENTES, R.; BORIE, E. \& BELTRÁN, V. Visualización radiográfica y macroscópica de cuartos molares: un reporte de cuatro casos en el maxilar. Int. J. Morphol., 30(1):115-118, 2012.

RESUMEN: Los dientes supernumerarios son definidos como la existencia de un mayor número de dientes en relación a la fórmula dental normal. El desarrollo de los dientes supernumerarios puede ocurrir en diferentes momentos de la vida y puede ser detectada, clínica o radiográficamente. La relación entre los dientes supernumerarios y los casos no sindrómicos han sido reportados de vez en cuando en la literatura. En este reporte se presentan cuatro casos de pacientes no sindrómicos con cuartos molares en la maxila, los cuales fueron descritos macroscópicamente y radiológicamente.

PALABRAS CLAVE: Cuarto molar; Diente supernumerario; Radiografía.

\section{REFERENCES}

Basdra, E. K.; Kiokpasoglou, M. \& Stellzig, A. The Class II Division 2 craniofacial type is associated with numerous congenital tooth anomalies. Eur. J. Orthod., 22:529-35, 2000.

Borie, E.; Oporto, G. \& Aracena, D. Dens Evaginatus in Hemophilic Patient: a case report. Int. J. Morphol., 28:375-8, 2010.

Celikoglu, M.; Kamak, H. \& Oktay, H. Prevalence and characteristics of supernumerary teeth in a non-syndrome Turkish population: Associated pathologies and proposed treatment. Med. Oral Patol. Oral Cir. Bucal, 15:e575-8, 2010.

Cortés, D.; Chappuzeau, E. \& Cortés, P. Cuartos Molares: Presentación de tres casos clínicos. Rev. Dent. Chile, 100:23-7, 2009.

De Oliveira Gomes, C.; Drummond, S. N.; Jham, B. C.; Abdo, E. 
N. \& Mesquita, R. A. A survey of 460 supernumerary teeth in Brazilian children and adolescents. Int. J. Paediatr. Dent., 18:98-106, 2008.

Desai, R. S. \& Shah, N. P. Multiple supernumerary teeth in two brothers: a case report. J. Oral Pathol. Med., 27:411-3, 2007.

Duncan, W. N. Supernumerary teeth from two mesoamerican archaeological contexts. Dent. Anthropol., 22:39-46, 2009.

Fuentes, R. \& Oporto, G. Ectopic and impacted third molar in retromolar zone. A Case Report. Int. J. Morphol., 27:35-8, 2009.

Gay, C.; Mateos, M.; España, A. \& Gargallo, J. Otras inclusiones dentarias: Mesiodens y otros dientes supernumerarios. Dientes temporales incluidos. Madrid, Ergon, 1999. pp.511-20.

Grimanis, G. A; Kyriakides, A. T. \& Spyropoulos, N. D. A survey on supernumerary molars. Quintessence Int., 22:989-95, 1991.

Hopcraft, M. Multiple supernumerary teeth. Case report. Aust. Dent. J., 43:17-9, 1998.

Kokten, G.; Balcioglu, H. \& Buyukertan, M. Supernumerary fourth and fifth molars: a report of two cases. J. Contemp. Dent. Pract., 4:67-76, 2009.

Leco Berrocal, M. I.; Martín Morales, J. F. \& Martínez González, J. M. An observational study of the frequency of supernumerary teeth in a population of 2000 patients. Med. Oral Patol. Oral Cir. Bucal, 12:e134-8, 2007.

Menardía-Pejuan, V.; Berini-Aytes, L. \& Gay-Escoda, C. Supernumerary molars. A review of 53 cases. Bull. Group Int. Res. Sci. Stomatol. Odontol., 42:101-5, 2000.

Orhan, A.; Ozer, L. \& Orhan, K. Familial occurrence of nonsyndromal multiple supernumerary teeth: a rare condition. Angle Orthod., 76:891-7, 2006.

Pindborg, J. J. Pathology of the Dental Hard Tissues. Copenhagen, Munksgaard, 1970.

Qaradaghi, I. F. Supernumerary Tooth: report of a rare case of a fourth mandibular molar. Rev. Clín. Pesq. Odontol., 5:157-60, 2009.

Rajab, L. D. \& Hamdan, M. A. Supernumerary teeth: review of the literature and a survey of 152 cases. Int. J. Paediatr. Dent., 12:244-54, 2002.

Refoua, Y. \& Arshad, M. An unusual case of bilateral maxillary and mandibular supernumerary teeth. J. Dent. Tehran. U. Med. Sci., 3:140-2, 2006.

Salcido-García, J. F.; Ledesma-Montes, C.; Hernández-Flores, F.; Pérez, D. \& Garcés-Ortíz, M. Frecuencia de dientes supernu- merarios en una población mexicana. Med. Oral Patol. Oral Cir. Bucal, 9:403-9, 2004.

Scheiner, M. A. \& Sampson, W. J. Supernumerary teeth: A review of the literature and four case reports. Aust. Dent. J., 42:160$5,1997$.

Stafne, E. C. Supernumerary teeth. Dent. Cosmos., 74:653-9, 1935.

Timocin, N.; Yalacin, S.; Ozgen, M.; Tanyeri, H. Supernumerary molars and paramolars. J. Nihon Univ. Sch. Dent., 36:145-50, 1994.

Uslu, O.; Akcam, M. O.; Evirgen, S. \& Cebeci, I. Prevalence of dental anomalies in various malocclusions. Am. J. Orthod. Dentofacial Orthop., 135:328-35, 2009.

\section{Dirección para correspondencia: \\ Ramón Fuentes Fernández \\ Departmento Odontología Integral \\ Facultad de Medicina \\ Universidad de la Frontera \\ Manuel Montt 112 \\ Temuco \\ CHILE}

Email: rfuentes@ufro.cl

Recibido : 20-09-2011

Aceptado: 20-10-2011 